\title{
Antihistamines for Allergic Rhinitis Treatment from the Viewpoint of Nonsedative Properties
}

\author{
Hideyuki Kawauchi ${ }^{1}$, Kazuhiko Yanai ${ }^{2,3, * \mathbb{C}}$, De-Yun Wang ${ }^{4} \mathbb{D}$, Koju Itahashi ${ }^{5}$ and \\ Kimihiro Okubo ${ }^{6}$ \\ 1 Department of Otorhinolaryngology, Shimane University, Faculty of Medicine, 89-1 Enya-cho, Izumo-shi, \\ Shimane 693-8501, Japan; kawauchi@med.shimane-u.ac.jp \\ 2 Department of Pharmacology, Tohoku University School of Medicine, 2-1 Seiryo-cho, Aoba-Ku, \\ Sendai 980-8575, Japan \\ 3 Cyclotron and Radioisotope Center, Tohoku University, 6-3 Aoba, Aramaki, Aoba-ku, Sendai 980-8578, Japan \\ 4 Department of Otolaryngology, Yong Loo Lin School of Medicine, National University of Singapore, 1E Kent \\ Ridge Road, Singapore 119228, Singapore; entwdy@nus.edu.sg \\ 5 Medical Science Section, Pharmaceutical R\&D Division, Meiji Seika Pharma Co., Ltd., Kyobashi 2-4-16, \\ Chuo-Ku, Tokyo 104-8002, Japan; kouju.itahashi@meiji.com \\ 6 Department of Otorhinolaryngology, Nippon Medical School, 1-1-5 Sendagi, Bunkyo-ku, \\ Tokyo 113-8602, Japan; ent-kimi@nms.ac.jp \\ * Correspondence: yanai@med.tohoku.ac.jp; Tel.: +81-22-717-8055
}

Received: 3 December 2018; Accepted: 29 December 2018; Published: 8 January 2019

check for updates

\begin{abstract}
Antihistamines targeting the histamine $\mathrm{H}_{1}$ receptor play an important role in improving and maintaining the quality of life of patients with allergic rhinitis. For more effective and safer use of second-generation drugs, which are recommended by various guidelines, a classification based on their detailed characteristics is necessary. Antihistamines for first-line therapy should not have central depressant/sedative activities. Sedative properties (drowsiness and impaired performance) are associated with the inhibition of central histamine neurons. Brain $\mathrm{H}_{1}$ receptor occupancy $\left(\mathrm{H}_{1} \mathrm{RO}\right)$ is a useful index shown to be correlated with indices based on clinical findings. Antihistamines are classified into non-sedating ( $<20 \%)$, less-sedating (20-50\%), and sedating $(\geq 50 \%)$ groups based on $\mathrm{H}_{1} \mathrm{RO}$. Among the non-sedating group, fexofenadine and bilastine are classified into "non-brain-penetrating antihistamines" based on the $\mathrm{H}_{1} \mathrm{RO}$. These two drugs have many common chemical properties. However, bilastine has more potent binding affinity to the $\mathrm{H}_{1}$ receptor, and its action tends to last longer. In well-controlled studies using objective indices, bilastine does not affect psychomotor or driving performance even at twice the usual dose (20 mg). Upon selecting antihistamines for allergic rhinitis, various situations should be taken into our consideration. This review summarizes that the non-brain-penetrating antihistamines should be chosen for the first-line therapy of mild allergic rhinitis.
\end{abstract}

Keywords: allergic rhinitis; antihistamine; bilastine; fexofenadine; $\mathrm{H}_{1}$ receptor occupancy; non-brain-penetrating

\section{Introduction}

Allergic rhinitis is one of the type I allergic diseases and IgE-mediated inflammation developing through exposure of the nasal mucosa to allergens [1,2]. When specific IgE antibodies bound to the Fc $\varepsilon$ receptors of mast cells or basophils once recognizes an allergen (antigen), histamine, leukotriene, platelet-activating factor, etc. are released from those cells, inducing immediate-type allergic reactions $[3,4]$. The nasal triad symptoms are paroxysmal and repetitive sneezing, running nose, and stuffy nose [1,2]. Allergic rhinitis is classified into continuous or intermittent types according 
to the duration of symptoms, and perennial or seasonal (pollinosis) types according to the difference in allergens $[1,2]$. The estimated number of patients with allergic rhinitis is estimated to be more than 500 million worldwide and 150 million in the Asia-Pacific region [1]. Particularly in Japan, the incidence of allergic rhinitis increased in number from $29.8 \%$ in 1998 to $39.4 \%$ in 2008 , and interestingly, the proportion of pollinosis increased during that period [2].

The treatments for allergic rhinitis could be divided into removal or avoidance of allergens, pharmaceutical treatment, immunotherapy, and surgical intervention. Among these, pharmaceutical treatment employing antihistamines, leukotriene receptor antagonists, topical steroids, vasoconstrictors, etc. play an important role in improving and maintaining the quality of life. In particular, antihistamines (oral, eye drop, and nasal drop formulations) are widely indicated for mild to severe conditions $[1,2,5]$. In fact, an observational study in Asia reported that patients with allergic rhinitis were most frequently $(\geq 50 \%$ ) treated with antihistamines (followed by nasal spray steroids; approximately $30 \%$ ) [6].

Antihistamines have a long history in their development. Antihistamines released earlier in the market are called first-generation antihistamines. Second-generation antihistamines were introduced around 1980 and later [7]. First-generation antihistamines inevitably exhibited central depressant/sedative activities. Moreover, they showed low specificity and adverse reactions (thirst, urinary retention, tachycardia, etc.) due to effects such as anticholinergic effects. Therefore, to overcome these drawbacks, various types of pharmacological improvements were performed during development of secondgeneration antihistamines [7-9].

Currently revised guidelines for the treatment of allergic rhinitis recommend the use of secondgeneration antihistamines [1,2]. However, because of a larger number of drug products in so called "antihistamines" category, understanding the pharmacological characteristics of individual drugs is essential for effective and safer use of antihistamines in clinical practice. Therefore, in this article, we will review pharmacological characteristics of antihistamines, focusing especially on nonsedative properties as an important point of these drugs. At the same time, we will summarize the characteristics of representative second-generation antihistamines and provide expert opinions regarding the favorable selection of antihistamines for the treatment of patients with allergic rhinitis based on international standards.

\section{Pharmacological Aspects Related to Sedation of Antihistamines}

\subsection{Histamine and Its Receptors}

Histamine is produced as a biological amine from L-histidine through the action of histidine decarboxylase. Histamine-producing cells include histamine neurons, gastric enterochromaffin-like cells, mast cells, and basophils [8]. The action of histamine is exhibited through four types of histamine receptors $\left(\mathrm{H}_{1}, \mathrm{H}_{2}, \mathrm{H}_{3}\right.$, and $\mathrm{H}_{4}$ receptors, all of which are G-protein-coupled receptors (GPCR)) and is related to neurotransmission, smooth muscle contraction, vascular permeability, gastric acid secretion, basophil functions, etc. $[9,10]$. $\mathrm{H}_{1}$ receptors, to which antihistamines for allergy treatment mainly bind, are distributed in various cells, such as central nervous system cells, smooth muscle cells (blood vessels and respiratory system), endothelial cells, chondrocytes, hepatocytes, dendrocytes, monocytes, neutrophils, and lymphocytes [10]. Incidentally, antihistamines targeting $\mathrm{H}_{1}$ receptors $\left(\mathrm{H}_{1}\right.$ antihistamines) are not structurally related to histamine; they are inverse agonists binding to receptor sites that are different from those of histamine [11,12]. Precise information on histamine and its receptors can be obtained from the web site of IUPHAR/BPS Guide to Pharmacology (http: //www.guidetopharmacology.org/).

The crystal structure of a complex between the $\mathrm{H}_{1}$ receptor and doxepin, a first-generation antihistamine, was elucidated in 2011 [13]. The $\mathrm{H}_{1}$ receptor has seven transmembrane helices, which is a characteristic common to GPCR, with the N-terminal outside and the C-terminal inside the cell. The configuration of the transmembrane helices of the receptor is similar to that of other GPCR. However, with regard to the between-helices loop structure, the similarity with other amine receptors 
is low [13]. Most amino acid residues residing at the doxepin binding site of the $\mathrm{H}_{1}$ receptor are highly conserved among amine receptors. However, amino acid residues interacting with phosphate ion are proper to the $\mathrm{H}_{1}$ receptor. In the docking model, a carboxyl group (negative charge) of second generation antihistamines (olopatadine, acrivastine, levocetirizine, and fexofenadine) is considered to bind with the binding site of the phosphate ion, and high specificity of these drugs toward the $\mathrm{H}_{1}$ receptor was suggested [13]. In the docking model, the carboxyl group of bilastine is also predicted to bind with the binding site of the phosphate ion of the $\mathrm{H}_{1}$ receptor [8]. Epinastine, desloratadine, loratadine, and rupatadine, which belong to an amino group type, have low specificity to the $\mathrm{H}_{1}$ receptor, and bind also with other GPCR.

\subsection{Sedative Potentials of Antihistamines and Their Classification Based on Brain $\mathrm{H}_{1}$ Receptor Occupancy}

Sedative properties of $\mathrm{H}_{1}$ antihistamines (drowsiness, impaired performance, etc.) are caused by inhibition of the functions of central histamine neurons [7-9]. The cell bodies of histamine neurons are localized in the hypothalamic tuberomammillary nucleus, with their nerve fibers being distributed widely from the whole brain to a part of the spinal cord to form a monoaminergic nerve system $[8,14,15]$. At an arousal state, histamine neurons are strongly excited to release histamine, and the released histamine strongly activates the function of the cerebral cortex either directly via $\mathrm{H}_{1}$ and $\mathrm{H}_{2}$ receptors or by exciting the acetylcholine neurons and noradrenaline neurons in the brainstem, the acetylcholine neurons in the substantia innominate, and the glutamine neurons in the hypothalamus. The activation of the cerebral cortex function by histamine neurons is closely associated with the maintenance of the arousal state [16], enhanced cognitive functions, and inhibition of appetite [17].

In order for antihistamines to exhibit sedative properties, they need to penetrate into the brain and bind with $\mathrm{H}_{1}$ receptors. Thus, the brain $\mathrm{H}_{1}$ receptor occupancy $\left(\mathrm{H}_{1} \mathrm{RO}\right)$ has been investigated as an index of sedative potential [18-22]. For the measurement of this index, $\left[{ }^{11} \mathrm{C}\right]$ doxepin and positron emission tomography are used (Figure 1) [18-25]. To cite an example, a study of the second-generation antihistamines fexofenadine and cetirizine [21] reported that the $\mathrm{H}_{1} \mathrm{RO}$ of fexofenadine (120 mg) was minimal $(-0.1 \%)$, whereas that of cetirizine $(20 \mathrm{mg})$ was moderate $(26.0 \%)$. In objective psychomotor tests in the same study, fexofenadine did not show significant differences from the placebo, and in some evaluation endpoints, the effects of fexofenadine were significantly less than those of cetirizine. With regard to subjective sleepiness, although cetirizine tended to increase sleepiness, fexofenadine did not show a significant difference from the placebo [21]. On a different note, while the first-generation hydroxyzine $(30 \mathrm{mg}$ ) significantly prolonged the break reaction time while driving a car compared to the placebo, fexofenadine $(120 \mathrm{mg})$ did not show a significant difference from the placebo [26]. Furthermore, the proportional impairment ratio (PIR) based on subjective feeling and objective performance was investigated as an index of sedation due to $\mathrm{H}_{1}$ antihistamines to rank many first- and second-generation antihistamines $[27,28]$. The results also showed differences in PIR among drugs as follows, fexofenadine, 0.00; cetirizine, 0.25 ; and hydroxyzine, 2.43 [27]. Thus, correlations among $\mathrm{PIR}$, the incidence rate of sedative effects, and $\mathrm{H}_{1} \mathrm{RO}$ measured by positron emission tomography have been confirmed $[8,9]$.

Yanai et al. measured the $\mathrm{H}_{1} \mathrm{RO}$ of many first- and second-generation antihistamines and proposed a classification of these drugs according to the level of the $\mathrm{H}_{1} \mathrm{RO}[8,9,29]$. The importance of $\mathrm{H}_{1} \mathrm{RO}$ as an index of nonsedative property of antihistamines was also confirmed at the "Consensus Group of New Generation of Antihistamines (CONGA)", which is an expert meeting sponsored by the British Society for Allergy and Clinical Immunology [30]. Antihistamines are classified into three groups based on the $\mathrm{H}_{1} \mathrm{RO}$ after a single oral administration: non-sedating $(<20 \%)$, less-sedating $(20-50 \%)$, and sedating ( $\geq 50 \%)$ groups. According to the measurement results by multiple research groups, the non-sedating group includes bilastine $(20 \mathrm{mg})$, fexofenadine $(60-120 \mathrm{mg})$, levocetirizine (5 mg), epinastine $(20 \mathrm{mg})$, ebastine $(10 \mathrm{mg})$, loratadine $(10 \mathrm{mg})$, terfenadine $(60 \mathrm{mg})$, cetirizine (10 mg), olopatadine (5 mg), and bepotastine (10 mg) [8] (Figure 2). The chemical structures of $\mathrm{H}_{1}$ antihistamines belonging to the non-sedating group are characterized by the presence of hydrophilic 
functional groups, i.e., carboxyl group (-COOH) and/or amino group $\left(-\mathrm{NH}_{2}\right)$ (Figure 3), which is considered to suppress the penetration through the blood-brain barrier (BBB).

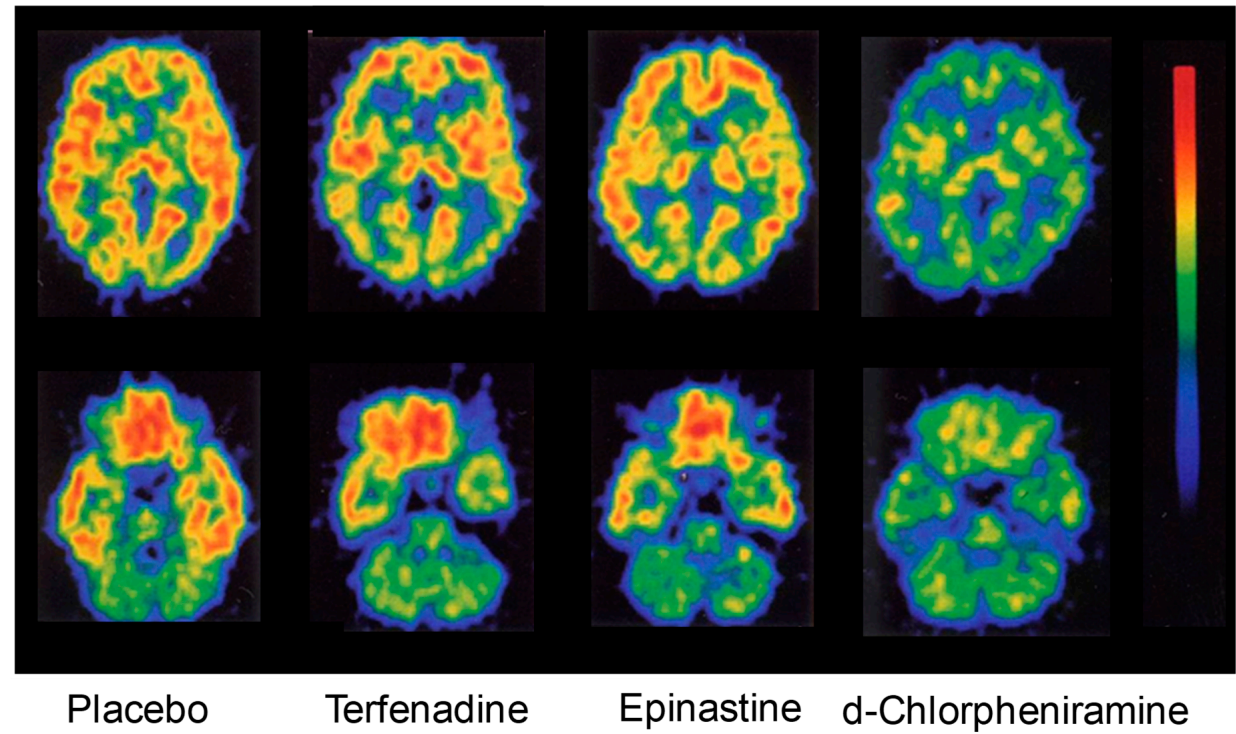

Figure 1. Early studies on positron emission tomography (PET) measurements of brain histamine $\mathrm{H}_{1}$ receptor occupancy. These images show radioactivity in horizontal brain sections at the striatal level (upper) and the cerebellar level (lower) after intravenous injection of $\left[{ }^{11} \mathrm{C}\right]$ doxepin into healthy volunteers. Terfenadine (60 mg), epinastine $(20 \mathrm{mg})$, or d-chlorpheniramine (2 $\mathrm{mg})$ was orally administered $1 \mathrm{~h}$ before the doxepin injection. For example, d-chlorpheniramine clearly decreased the accumulation of the $\left[{ }^{11} \mathrm{C}\right]$ ligand in the brain, resulting in a histamine $\mathrm{H}_{1}$ receptor occupancy of $76.8 \%$. The brain histamine $\mathrm{H}_{1}$ receptor occupancy (\%) was defined and calculated as described [18]. Modified based on [18].

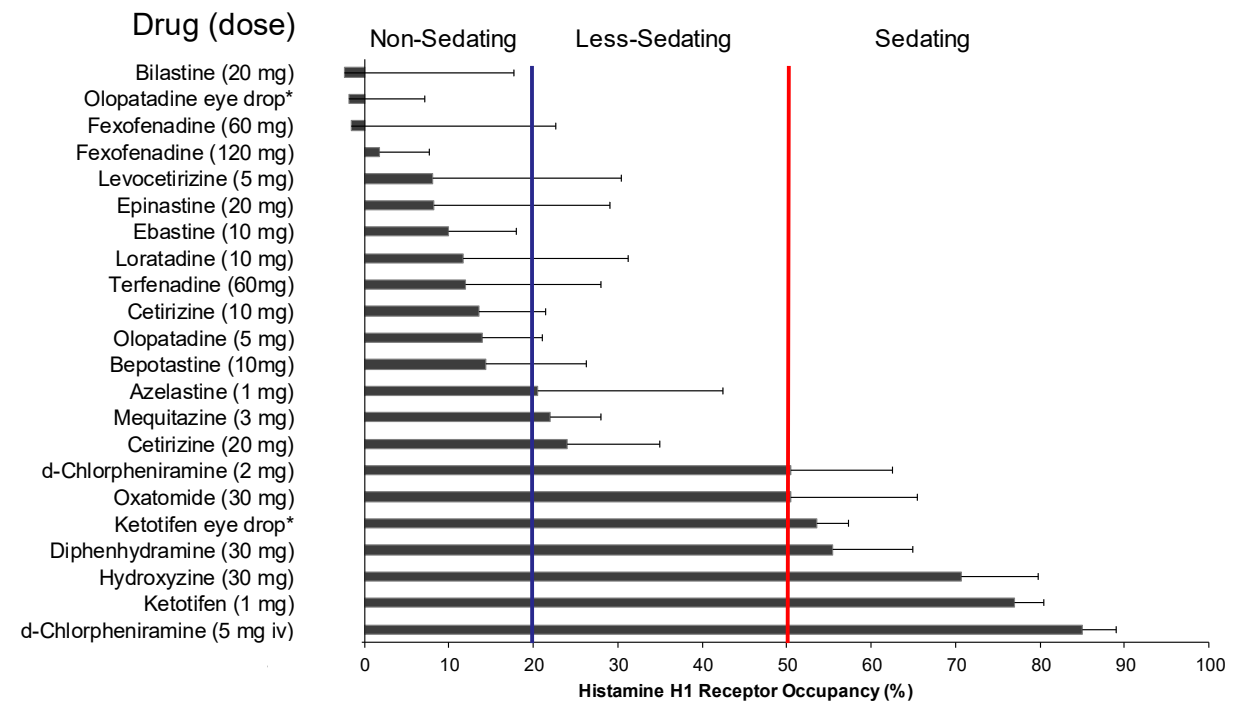

Figure 2. Brain histamine $\mathrm{H}_{1}$ receptor occupancies of various antihistamines and classification for sedating actions. The occupancy data are represented as the mean $\pm \mathrm{SD}$ of measurements in $\left[{ }^{11} \mathrm{C}\right]$ doxepin-positron emission tomography after oral single-dose, eye drop ${ }^{*}$ ), or intravenous (iv) administration of the drugs; the data were obtained by more than one research group. When $\mathrm{H}_{1}$ receptor occupancy was $20 \%$ or lower, impaired performance was not observed in a simultaneously performed cognitive function test $[19,21]$, and therefore, the drug could be classified as "non-sedating" (Modified based on [8]). 


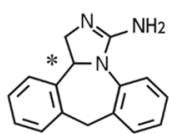

$\mathrm{MW}=249.3$

$(\mathrm{R})(\mathrm{S})$ Epinastine

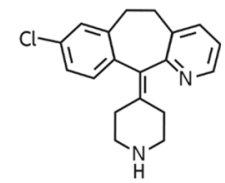

$\mathrm{MW}=310.8$

Desloratadine

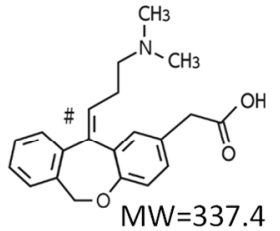

(Z)Olopatadine

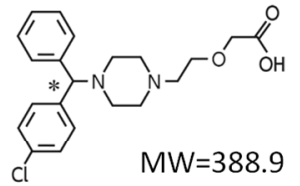

$(\mathrm{R})(\mathrm{S})$ Cetirizine

(R)Levocetirizine

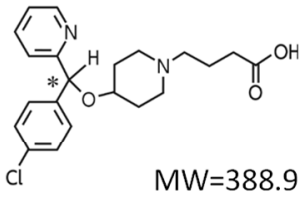

(S)Bepotastine
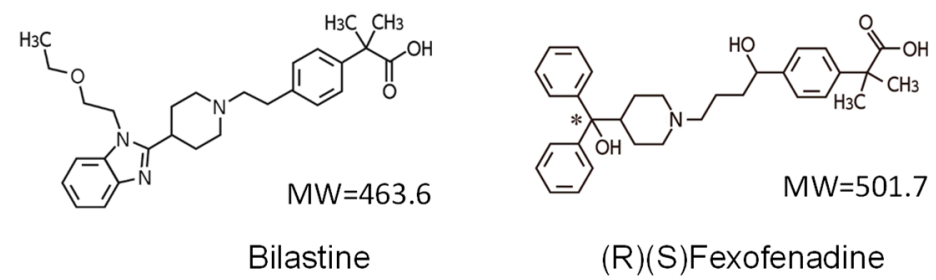

Figure 3. Chemical structures of several non-sedating antihistamines. There are two types of non-sedating antihistamines: the amino group type (epinastine and desloratadine) and the carboxy group type (the others; zwitterionic compounds). MW, molecular weight; (R), (S), optical isomers; (Z), geometric isomer; *, the carbon atom that is related to optical isomerism; \#, the double bond that is related to the structurally different geometric isomer (cis-trans isomer) without optical isomerism. The carboxy group types are characterized by high specificity to $\mathrm{H}_{1} \mathrm{R}$, while the amino group types bind to other GPCR receptors such as muscarinic receptors. Note that the mean molecular weight of marketed CNS drugs is approximately $310 \mathrm{Da}$ and that the molecular weights of fexofenadine and bilastine are larger than others.

\subsection{Non-Brain-Penetrating Antihistamines: Bilastine and Fexofenadine}

Among the antihistamines belonging to the non-sedating group, the $\mathrm{H}_{1} \mathrm{RO}$ s of bilastine and fexofenadine, in particular, are nearly $0 \%$ [21,22,31] (Figure 2), and these antihistamines minimally penetrate into the brain. Thus, these two drugs can be distinguished as "non-brain-penetrating antihistamines" [32] (Figure 4). Both bilastine and fexofenadine are zwitterions, having both a positive charge $\left(\mathrm{N}^{+}\right)$and a negative charge $\left(\mathrm{COO}^{-}\right)$within the molecule. In the docking simulation, their binding modalities with the $\mathrm{H}_{1}$ receptor are similar [8]. In addition, the molecular weights of both of these drugs are larger than those of non-sedating antihistamines (Figure 3), their acid-base dissociation constants are similar (bilastine, $\mathrm{pKa}_{1}=4.06$ and $\mathrm{pKa}_{2}=9.43$; fexofenadine, $\mathrm{pKa} \mathrm{a}_{1}=4.04$ and $\mathrm{pKa}_{2}=9.01$ as predicted values in the DrugBank (https://www.drugbank.ca/)), and they are completely dissociated (ionized) at the physiological pH (Figure 5). Most non-sedating $\mathrm{H}_{1}$ antihistamines, including these drugs, are substrates of P-glycoprotein [33,34], and thus their penetration through the BBB is restricted. However, the levels of P-glycoprotein contribution to brain penetration differ depending on individual drugs. In addition to hydrophobicity, molecular weight, and electric charge (net charge under physiological conditions) of the compounds, many other factors, including cytochrome P450 enzymes, enantiomers, etc., are considered to be involved in the BBB or brain penetration [8]. In the case of passive diffusion, brain penetration increases with decreasing molecular weights. 


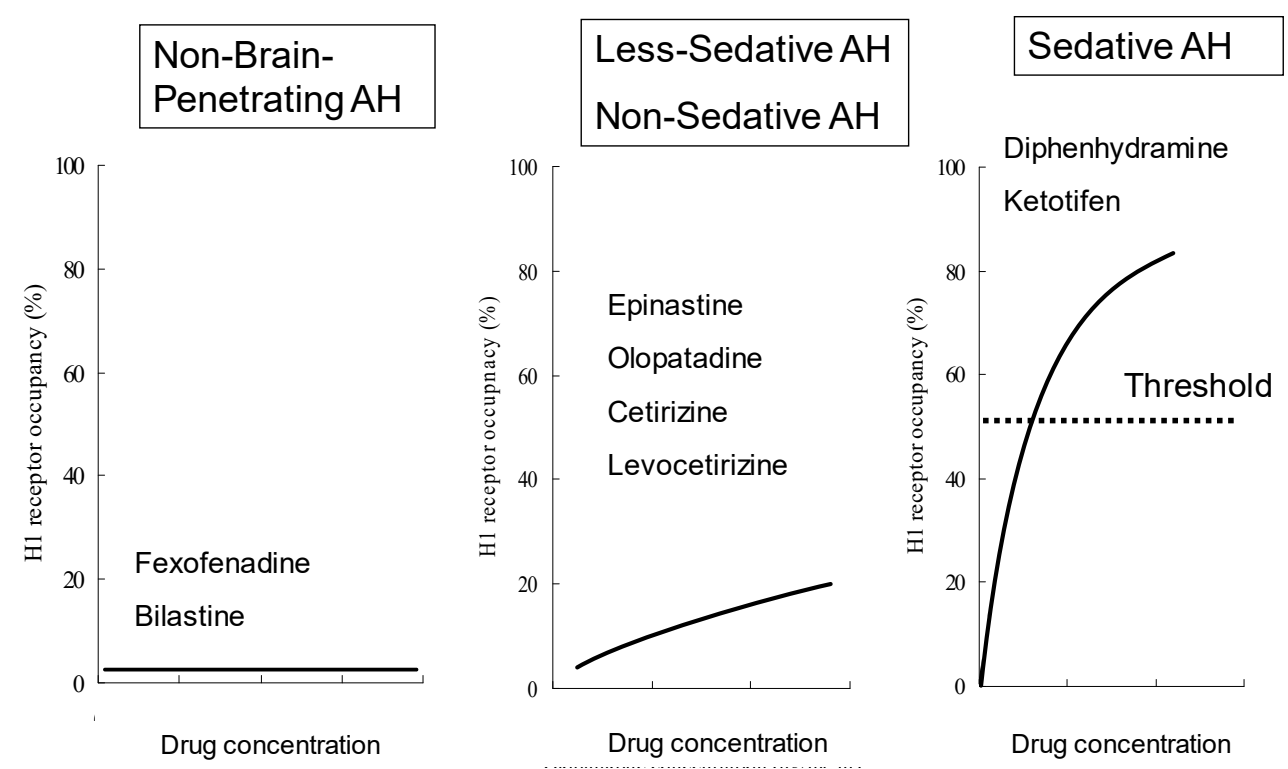

Figure 4. A new classification of antihistamines based on brain histamine $\mathrm{H}_{1}$ receptor occupancy. Antihistamines can be classified into non-sedating, less-sedating, and sedating groups based on the $\mathrm{H}_{1} \mathrm{RO}$ and mean plasma concentration of the drugs measured during positron emission tomography, as previously reported [9,29]. In this figure, the concept of "non-brain-penetrating" [32] is included. The $\mathrm{H}_{1}$ ROs of non-brain-penetrating antihistamines are nearly zero and not correlated to the plasma concentrations of the drugs. The $\mathrm{H}_{1} \mathrm{ROs}$ of non-sedating and less-sedating antihistamines, in the range of up to $20 \%$ (for non-sedating) or $50 \%$ (for less-sedating), are proportional to some degree to the plasma concentrations of the drugs and have increased brain penetration. Sedative antihistamines rapidly penetrate the brain and show $50 \%$ or more $\mathrm{H}_{1} \mathrm{RO}$, associated with increasing plasma drug concentrations. AH, antihistamines. (Modified based on [9].)

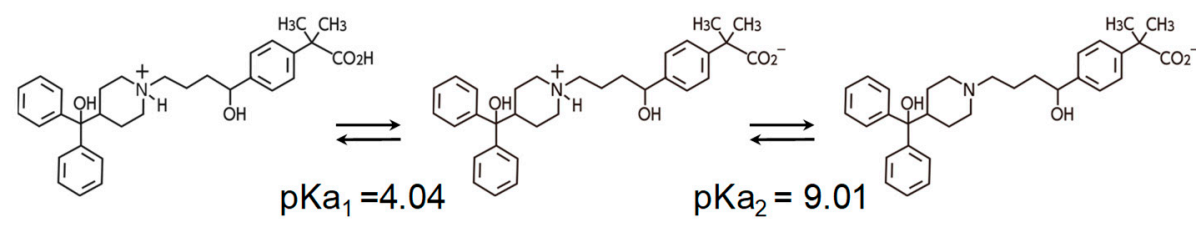

\section{Dissociation of Fexofenadine}

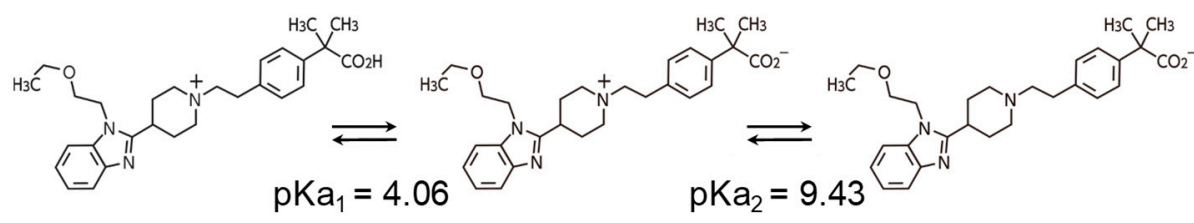

Dissociation of Bilastine

Figure 5. Acid-Base Dissociation Constant (pKa). Non-sedating antihistamines of the carboxy group type have zwitterionic properties with positive and negative charges at two sites. The $\mathrm{pKa}$ of bilastine and fexofenadine are nearly the same, and these drugs are mostly dissociated at the physiological $\mathrm{pH}$, making them difficult to penetrate into the brain. Non-sedating antihistamines are not potent inhibitors of P-glycoprotein; therefore, they are considered not to penetrate into the brain because of complex reasons, including molecular weight and $\mathrm{pKa}$. 
With regard to the binding affinity to the $\mathrm{H}_{1}$ receptors, in an in vitro experiment using a Chinese hamster ovary cell line expressing human $\mathrm{H}_{1}$ receptors and $\left[{ }^{3} \mathrm{H}\right]$ pyrilamine, the Ki values of fexofenadine, loratadine, cetirizine, olopatadine, levocabastine, and desloratadine were 218, 231, $101,34,19$, and $3.0 \mathrm{nM}$, respectively [35]. Although the evaluation system was different, in an in vitro experiment using the inhibition of $\left[{ }^{3} \mathrm{H}\right]$ pyrilamine binding to the $\mathrm{H}_{1}$ receptor of a guinea pig cerebellum-derived membrane sample as an index, the Ki values of fexofenadine and bilastine were 246 and $44 \mathrm{nM}$, respectively [36]. In addition, in an in vitro experiment using HEK293 T cells expressing human $\mathrm{H}_{1}$ receptors and $\left[{ }^{3} \mathrm{H}\right]$ pyrilamine, the Ki values of fexofenadine and bilastine were approximately 32 and $8.7 \mathrm{nM}$, respectively [37]. In summary, among the second-generation antihistamines, while bilastine has a moderate $\mathrm{H}_{1}$ receptor affinity, the affinity of fexofenadine is relatively weak; thus, this latter drug needs a higher dosage to exhibit a similar level of activity to bilastine.

\subsection{Residual Effects by Sedating Antihistamines}

The half-life of $\mathrm{H}_{1}$ antihistamines in the brain can be longer than that in the plasma; therefore, caution is necessary. Measurement of the $\mathrm{H}_{1} \mathrm{RO} 3$ to $23 \mathrm{~h}$ after the administration of the sedating antihistamines, diphenhydramine $(50 \mathrm{mg})$ and ketotifen $(1 \mathrm{mg})$, suggested that their half-lives were approximately 30 and $45 \mathrm{~h}$, respectively [32]. The half-lives of these drugs in the plasma were 6 to $8 \mathrm{~h}$. Thus, the half-lives in the brain were approximately five times longer than those in the plasma, showing that the half-lives in tissues and those in the blood can be different. It has been reported that sedating antihistamines affect the circadian sleep/wake cycle, delaying the occurrence of REM sleep during sleep or shortening the sleeping time and that drowsiness and impaired performance are observed on the next day as an aftereffect [38]. These observations suggest involvement of brain pharmacokinetics in sedative effects of these drugs. With regard to local administration of sedating antihistamines, it should be well recognized that occupancy of brain $\mathrm{H}_{1}$ receptors through eye drop administration has been confirmed [32] (Figure 2) and that brain penetration can also occur through nasal spray [39].

\section{Clinical Aspects of Non-Sedating Antihistamines}

\subsection{Clinical Profiles of Representative Second-Generation Antihistamines}

Clinical profiles of bilastine, fexofenadine, cetirizine, levocetirizine, loratadine, desloratadine, and ebastine are shown in Table 1. Loratadine and desloratadine, belonging to the amino group type, have anticholinergic activity, whereas bilastine, fexofenadine, cetirizine, levocetirizine, and ebastine, belonging to the carboxy group type, show high specificity toward $\mathrm{H}_{1}$ receptor antagonistic activity. All of these drugs are indicated for allergic rhinitis and urticaria. These drugs tend to have a short time to maximum plasma concentration $\left(T_{\max }\right.$ ) (within approximately $3 \mathrm{~h}$ ) and a long elimination half-life $\left(\mathrm{t}_{\frac{1}{2}}\right)$ (except levocetirizine and loratadine: $\geq 10 \mathrm{~h}$ ). The frequency of dosing of fexofenadine is twice daily and that of all other drugs is once daily in Japan. Bilastine, fexofenadine, and cetirizine are not metabolized or are minimally metabolized. Bilastine and fexofenadine do not require dose adjustment according to the level of hepatic dysfunction. These two drugs do not require dose adjustment for patients with renal dysfunction either. As for all the drugs shown in Table 1, caution regarding the induction of drowsiness is required while the patients are being treated. However, they are allowed to drive a car. The antihistamines that most satisfy the requirements for oral $\mathrm{H}_{1}$ antihistamines described in the Allergic Rhinitis and its Impact on Asthma (ARIA) guidelines [1] are bilastine and fexofenadine [7]. Among the seven drugs in Table 1, bilastine alone is not indicated for pediatric use ( $<12$ years of age) in Japan. In addition, because bilastine is affected by food ingestion, it is described in the package insert that it should be taken on an empty stomach. Incidentally, it should be noted that non-sedating antihistamines of zwitterion type have the same properties to some degree. Because the organic anion transporting peptides that are associated with the absorption of fexofenadine are 
inhibited by grapefruit juice [40], concomitant ingestion of the drug and grapefruit juice should be avoided. The absorption of bilastine was similarly decreased by the co-administration of grapefruit juice. Antihistamines should be properly selected for individual patients after fully understanding these characteristics.

\subsection{Efficacy for Seasonal Allergic Rhinitis}

In a multicenter, randomized, double-blind, parallel-group comparative study in 683 patients with seasonal allergic rhinitis (SAR) using oral bilastine $(20 \mathrm{mg})$, cetirizine $(10 \mathrm{mg})$, and placebo once daily for 14 days [41], both bilastine and cetirizine significantly reduced the area under the curve (AUC) of reflective total symptom score (TSS: nasal symptom score [NSS] + non-nasal symptom score [NNSS]) over 14 days of treatment compared to placebo (76.5 and 72.3, respectively, for bilastine and cetirizine, vs. 100.6 for placebo; $p<0.001$ (Analysis of Variance, ANOVA)). In both drugs, the rates of decreases from the baseline in both NSS (total and individual for nasal obstruction, rhinorrhea, sneezing, and itching) and NNSS (total and individual for ocular tearing, redness, and itching) were nearly the same and were significantly larger than those in the placebo. Furthermore, when the overall discomfort score was used as an index of discomfort associated with allergic rhinitis, the efficacies of bilastine and cetirizine were similar. In this study, the incidence rate of somnolence in the bilastine group was significantly lower than that in the cetirizine group ( $1.8 \%$ vs. $7.5 \%, p<0.001$ [ $\mathrm{X}^{2}$ test]; placebo, $\left.2.2 \%\right)$.

In a multicenter, randomized, double-blind, parallel-group comparative study in 721 patients with SAR using oral bilastine $(20 \mathrm{mg})$, desloratadine $(5 \mathrm{mg})$, and placebo once daily for 14 days [42], bilastine and desloratadine significantly reduced the TSS-AUC compared to placebo (98.4 and 100.5, respectively, for bilastine and desloratadine vs. 118.4 for placebo; $p<0.001$ [ANOVA]). In addition, when NSS, NNSS, and the score of discomfort associated with rhinitis were used as indices, these drugs showed similar levels of efficacy. In this study, the incidence rates of adverse events in the bilastine group and the desloratadine group were nearly the same.

A randomized, double-blind, 4-way crossover study of bilastine $(20 \mathrm{mg})$, cetirizine (10 $\mathrm{mg})$, fexofenadine $(120 \mathrm{mg})$, and the placebo was conducted in 75 patients with SAR using a Vienna challenge chamber, which enabled artificial exposure to pollens [43]. In this study, drugs were administered $2 \mathrm{~h}$ after the start of $6 \mathrm{~h}$-pollen exposure. Significant decreases in the total NSS (TNSS) in individual drug treatment groups compared to the placebo group were observed until $4 \mathrm{~h}$ after drug administration. When the patients were again exposed to pollen 22 to $26 \mathrm{~h}$ after the drug administration (day 2), the increase in TNSS was significantly inhibited in either drug treatment group compared to the placebo group. The level of the inhibition was stronger in the cetirizine group than in the fexofenadine group. In addition, with regard to the decrease in the amount of nasal secretion and the decrease in the global symptom scale (the composite score for nasal obstruction, rhinorrhea, itchy nose, sneezing, watery eyes, itchy and red eyes, cough, itchy throat, and itchy ears) on day 2 , the effects of bilastine and cetirizine were more potent, and their durations of action were longer than those of fexofenadine. Furthermore, in a randomized, double-blind, 4-way crossover study of bilastine (10 or $20 \mathrm{mg}$ ), fexofenadine (60 mg, twice with $12 \mathrm{~h}$ interval), and placebo in 136 Japanese patients with SAR (Japanese cedar pollinosis) using an OHIO chamber [44], the TNSS of the bilastine 20-mg group was significantly lower than that of the fexofenadine group until $3 \mathrm{~h}$ after the treatment. 
Table 1. Clinical profiles of representative second-generation $\mathrm{H}_{1}$ antihistamines *

\begin{tabular}{|c|c|c|c|c|c|c|c|}
\hline Characteristic & Bilastine & Fexofenadine & Cetirizine & Levocetirizine & Loratadine & Desloratadine & Ebastine \\
\hline $\mathrm{H}_{1}$ receptor selectivity & +++ & + & + & ++ & + & ++ & ++ \\
\hline $\begin{array}{l}\text { Affinity for } \mathrm{H}_{2 / 3} \\
\text { receptors }\end{array}$ & \pm & \pm & \pm & \pm & \pm & \pm & + \\
\hline Metabolism & Not metabolized & \pm & \pm & ++ & +++ & +++ & +++ \\
\hline $\mathrm{t}_{\max }(\mathrm{h})$ & 1.3 & $1-3$ & 1.0 & 0.9 & $1.0-1.5$ & 3.0 & $\begin{array}{c}2.6-4.0 \\
\text { (carebastine } \\
\text { metabolite) }\end{array}$ \\
\hline $\mathrm{t}_{1 / 2}(\mathrm{~h})$ & 14.5 & $11-15$ & 10.0 & 7.9 & 8.4 & 27.0 & $\begin{array}{c}\text { 15-19 (carebastine } \\
\text { metabolite) }\end{array}$ \\
\hline $\begin{array}{l}\text { Indicated for allergic } \\
\text { rhinoconjunctivitis? }\end{array}$ & Yes & No & $\begin{array}{c}\text { Yes/No (some but } \\
\text { not all } \\
\text { formulations) }\end{array}$ & No & No & No & No \\
\hline $\begin{array}{l}\text { Indicated for allergic } \\
\text { rhinitis? }\end{array}$ & Yes & Yes & Yes & Yes & Yes & Yes & Yes \\
\hline Indicated for urticaria? & Yes & Yes & Yes & Yes & Yes & Yes & Yes \\
\hline Pediatric indication? & $\begin{array}{l}\text { No (ongoing } \\
\text { studies) }\end{array}$ & children $>3$ years & $\begin{array}{l}\text { children } 6-12 \\
\text { years }\end{array}$ & children $>2$ years & children > 2 years & children $>1$ year & children $>2$ years \\
\hline $\begin{array}{l}\text { Dosage adjustment in } \\
\text { hepatic impairment? }\end{array}$ & No & No & $\begin{array}{l}\text { Yes (if concomitant } \\
\text { renal dysfunction) }\end{array}$ & $\begin{array}{l}\text { Yes (if concomitant renal } \\
\text { dysfunction) }\end{array}$ & $\begin{array}{l}\text { Yes (severe } \\
\text { disease) }\end{array}$ & Not mentioned & $\begin{array}{l}\text { Caution (in mild } \\
\text { to moderate) }\end{array}$ \\
\hline $\begin{array}{l}\text { Dosage adjustment in } \\
\text { elderly? }\end{array}$ & No & No & $\begin{array}{l}\text { No (if renal } \\
\text { function OK) }\end{array}$ & $\begin{array}{l}\text { Yes (for concomitant } \\
\text { moderate-to-severe } \\
\text { renal impairment) }\end{array}$ & No & Not mentioned & No \\
\hline Interaction with food? & $\begin{array}{l}\text { Yes (give on empty } \\
\text { stomach) }\end{array}$ & Not mentioned & No & No & No & No & No \\
\hline $\begin{array}{c}\text { Use in pregnancy and } \\
\text { lactation? }\end{array}$ & $\begin{array}{l}\text { Caution (very } \\
\text { limited data) }\end{array}$ & No & Caution & Caution & No & No & No \\
\hline
\end{tabular}


Table 1. Cont.

\begin{tabular}{|c|c|c|c|c|c|c|c|}
\hline Characteristic & Bilastine & Fexofenadine & Cetirizine & Levocetirizine & Loratadine & Desloratadine & Ebastine \\
\hline $\begin{array}{l}\text { Clinically relevant drug } \\
\text { interactions? }\end{array}$ & No & Yes (antacids) & No & $\begin{array}{l}\text { Unlikely (no available } \\
\text { data) }\end{array}$ & $\begin{array}{l}\text { Potential (with } \\
\text { inhibitors of } \\
\text { CYP3A4 and } \\
\text { CYP2D6) }\end{array}$ & No & Caution \\
\hline $\begin{array}{l}\text { Interaction with } \\
\quad \text { alcohol? }\end{array}$ & No & Not mentioned & Caution & Caution & No & No & No \\
\hline $\begin{array}{l}\text { Can patients drive and } \\
\text { operate machinery (i.e., } \\
\text { lack of sedative } \\
\text { potential)? }\end{array}$ & $\begin{array}{l}\text { Yes (caution: } \\
\text { drowsiness) }\end{array}$ & $\begin{array}{l}\text { Yes (impairment } \\
\text { unlikely) }\end{array}$ & $\begin{array}{l}\text { Yes (check drug } \\
\text { response when } \\
\text { intending to drive) }\end{array}$ & $\begin{array}{l}\text { Yes (check drug } \\
\text { response when } \\
\text { intending to drive) }\end{array}$ & $\begin{array}{l}\text { Yes (caution: } \\
\text { drowsiness) }\end{array}$ & $\begin{array}{l}\text { Yes (caution: } \\
\text { drowsiness) }\end{array}$ & $\begin{array}{l}\text { Yes (caution: } \\
\text { somnolence) }\end{array}$ \\
\hline Contraindications & None & None & $\begin{array}{l}\text { Severe renal } \\
\text { impairment }\end{array}$ & Severe renal impairment & None & None & $\begin{array}{c}\text { Severe hepatic } \\
\text { impairment }\end{array}$ \\
\hline $\begin{array}{c}\text { Number of ARIA } \\
\text { recommended } \\
\text { antihistamine properties } \\
\ddagger\end{array}$ & 10 & 9.5 & 6 & 6.5 & 6.5 & 6.5 & 6.5 \\
\hline
\end{tabular}


The efficacy of bilastine in patients with SAR was nearly the same as that of cetirizine and desloratadine and was better than that of fexofenadine [41-44], and the induction of somnolence by bilastine was weaker than that by cetirizine [41]. Incidentally, although details are not described here, bilastine was shown to be as effective as cetirizine and fexofenadine for perennial allergic rhinitis (PAR) $[45,46]$. The incidence rates of somnolence due to bilastine (20 $\mathrm{mg}$ once daily) and fexofenadine (60 mg twice daily) administered for 2 weeks in Japanese patients with PAR were $0.8 \%$ and $0.4 \%$ [46].

\subsection{Central Nervous System Safety of Bilastine}

Psychomotor performance was evaluated using multiple objective tests (evaluations of motor activity (Fine Motoric Test, FMT), perception (Critical Flicker-Fusion Frequency Test, CFF), attention ("d2" Cancellation Test, D2T), and associative integration (Simple Reaction Time, SRT)) in a randomized, double-blind, 5-way crossover study in 20 healthy subjects using bilastine (20,40, or $80 \mathrm{mg}$ ), hydroxyzine $(25 \mathrm{mg})$, and placebo once daily for 7 days [47]. Significant psychomotor impairment compared with the placebo was observed after single dose administrations (1 day) of $80 \mathrm{mg}$ bilastine and hydroxyzine. More tests showed significant results with hydroxyzine (SRT, CFF, and D2T) than with bilastine (SRT and CFF). However, after repeated administration (7 days), no significant psychomotor impairment was observed with either of the drugs. Regardless of single or repeated administration, no psychomotor impairment was observed with 20 and $40 \mathrm{mg}$ bilastine.

In a randomized, double-blind, 4-way crossover study in 22 healthy subjects using bilastine (20 or $40 \mathrm{mg}$ ), hydroxyzine (50 mg), and placebo once daily for 8 days [48], the effect on driving performance was evaluated using standard deviations of lateral position (SDLP, a measure of car weaving [49]) as an index. Hydroxyzine alone showed significantly larger SDLP compared to placebo both after a single dose (day 1) and repeated dose (day 8). No significant change in SDLP was observed in either 20 or $40 \mathrm{mg}$ bilastine.

In a randomized, double-blind, 6-way crossover study in 24 healthy subjects using concomitant bilastine (20 or $80 \mathrm{mg})$, cetirizine $(10 \mathrm{mg})$, or hydroxyzine $(25 \mathrm{mg})$ and alcohol $(0.8 \mathrm{~g} / \mathrm{kg})$, alcohol alone (+drug placebo), and placebos (alcohol placebo and drug placebo) [50], psychomotor performance was evaluated by objective tests (including FMT, CFF, D2T, and SRT). Significant psychomotor impairment compared to the placebo was observed in any of the concomitant administrations. Significant psychomotor impairment compared to alcohol alone was observed in any of the concomitant administrations of $80 \mathrm{mg}$ bilastine, cetirizine, or hydroxyzine with alcohol. The levels of psychomotor impairment with $80 \mathrm{mg}$ bilastine and hydroxyzine were nearly the same, and the level with cetirizine was a little lower than the levels of the above. The level of psychomotor impairment was nearly the same between concomitant bilastine $(20 \mathrm{mg})$ and alcohol and alcohol alone.

As discussed above, bilastine at the usual dose $(20 \mathrm{mg})$ and twice the dose $(40 \mathrm{mg})$ did not show impaired performance due to sedative activity $[47,48]$; in addition, the drug did not show alcohol interaction at its usual dose $(20 \mathrm{mg})[50]$.

\section{Conclusions}

The $\mathrm{H}_{1} \mathrm{RO}$ is useful as an index of antihistamines, and based on it, antihistamines have been classified into non-sedating, less-sedating, and sedating groups. Among the drugs in the non-sedating group, bilastine and fexofenadine do not show occupancy of the brain $\mathrm{H}_{1}$ receptors at their usual doses; thus, they can be referred to as "non-brain-penetrating antihistamines". In addition to the fact that they are both zwitterions, bilastine and fexofenadine are chemically very similar in many aspects. However, bilastine has a higher affinity to the $\mathrm{H}_{1}$ receptor than fexofenadine. Because no substantial differences in clinical efficacy are observed among representative second-generation antihistamines, one of the important points in selecting these drugs is brain penetration and the presence or absence of sedative effect, which are associated with safety. Bilastine has been shown not to affect psychomotor performance and driving performance even at the dose of $40 \mathrm{mg}$, which is twice the usual dose, 
by well-controlled studies using objective indices, and thus is considered to be a useful drug for allergic rhinitis. Currently, however, bilastine is not indicated for pediatric use in Japan.

\section{Expert Opinion}

As for antihistamines used for the treatment of allergic rhinitis, drugs not only of "the second generation" but those that have been confirmed to be non-sedating should be recommended [30,51]. The first-generation antihistamines generally have potent sedative effect and also other adverse effects (adverse events such as anticholinergic effect); however, their efficacy is not necessarily more potent than that of second-generation antihistamines. The term "second generation" refers to the classification based on the era they were developed, and thus not all the second-generation antihistamines are non-sedating or less-sedating. It should be noted that sedating drugs, such as ketotifen, can be included in the second-generation drugs (Sections 1 and 2.4). Incidentally, ingestion of sedating antihistamines as a sleep-inducing drug before sleep should be avoided, because the use of such drugs is likely to deteriorate the quality of sleep and also because the effect may continue to the next day (Section 2.4). The efficacy of second-generation antihistamines against allergic rhinitis is mostly similar (Section 3.2); however, it is important to select the drugs to be used in view of nonsedative properties. Fexofenadine, bilastine, desloratadine, and loratadine are recommended in the "Guidelines for the Handling of the Drugs Used for Aircraft Crew" prepared recently by the Ministry of Land, Infrastructure, and Transport of Japan. However, as for loratadine, a mild sedative effect is reported based on studies of $\mathrm{H}_{1} \mathrm{RO}$ and cognitive functions. Therefore, further study is necessary.

Although the utility of $\mathrm{H}_{1} \mathrm{RO}$ in assessing the sedative potential of antihistamines has been widely recognized, there still remain issues to be addressed further. The reason why $\mathrm{H}_{1} \mathrm{RO}$ is usually measured in healthy young men is because the amount of brain $\mathrm{H}_{1}$ receptors (the amount of bound $\left[{ }^{11} \mathrm{C}\right]$ doxepin) is different between sexes and ages. For example, the amount is greater in women than in men, and it decreases with increasing age $[8,25]$. Details are not known regarding, for example, whether the $\mathrm{H}_{1} \mathrm{ROs}$ in patients with allergic diseases are the same as those in healthy people, or whether the results of repeated administration are correlated with those of conventional single dose administration, despite the observation that, depending on the drug, $\mathrm{H}_{1} \mathrm{RO}$ is increased by repeated administration [52]. However, based on the past findings, the correlations between the $\mathrm{H}_{1} \mathrm{RO}$ at single dose administration of various antihistamines and the evaluation indices of sedation based on clinical findings have been shown. Therefore, the results from the current measurement methods are definitely useful (Section 2.2).

According to the classification based on the $\mathrm{H}_{1} \mathrm{RO}$, fexofenadine and bilastine can be considered to be distinguished from other second-generation antihistamines as non-brain-penetrating antihistamines. In addition to their chemical properties, these two compounds have similar adaptability to the requirements of ideal antihistamines described in the ARIA guidelines [1]. However, there are some differences between the two drugs: bilastine has a stronger $\mathrm{H}_{1}$ receptor binding potency than fexofenadine; the dosing frequency of bilastine is once daily, while that of fexofenadine is twice daily; and bilastine is yet to be indicated for pediatric use (Sections 2.3 and 3.1). Judging from efficacy results from clinical studies, pharmacological findings regarding non-sedating properties, and clinical study results, bilastine may be one of the best options for $\mathrm{H}_{1}$ antihistamines for allergic rhinitis (Section 2.3, Section 3.2, and Section 3.3). The safety and tolerability of $10 \mathrm{mg}$ bilastine once daily for 12 weeks in children ( $\geq 2$ to $<12$ years of age) have already been confirmed [53]; thus, its indication expansion to pediatric use is expected in Japan.

With regard to bilastine, impaired performance was not observed even at the dose of $40 \mathrm{mg}$, which is twice its usual dose, in healthy subjects (Section 3.3). The EAACI/GA ${ }^{2} \mathrm{LEN} / \mathrm{EDF} / \mathrm{WAO}$ guidelines regarding urticaria [54] recommend that, for the secondary treatment, the amount of modern second-generation $\mathrm{H}_{1}$-antihistamines be increased by four times, citing the evidence from bilastine [54]. However, generally, increasing the dose of bilastine to $80 \mathrm{mg}$ should be avoided as much as possible because, despite its excellent efficacy against urticaria and histamine-induced skin 
symptoms [7,55-57], a study reported that the drug affected psychomotor performance at $80 \mathrm{mg}$ [47]. It will be of significance to obtain the $\mathrm{H}_{1} \mathrm{RO}$ of bilastine when the dose is increased to 40 and $80 \mathrm{mg}$.

In the ARIA guidelines, the efficacy in nasal congestion, etc. are listed as requirements for the efficacy of oral $\mathrm{H}_{1}$ antihistamines [1]. In other words, these drugs are considered to have concomitant anti-inflammatory effects [11,12]. In fact, a basic study using $\mathrm{H}_{1}$ receptor gene knockout mice reported that $\mathrm{H}_{1}$ receptor blockage inhibits the Th1 cytokines, interferon and IL-2, and increases the Th2 cytokines, IL-4 and IL-13 [58]. However, because clinical effects considered to be due to anti-inflammatory effect are mostly empirical, the selection of antihistamines should be based on the potency of the activity on $\mathrm{H}_{1}$ receptors. When efficacy seems inadequate at usual doses, it may be effective to increase the dose. However, risks associated with central depressant/sedative activities, anticholinergic effects, etc. should be thoroughly considered. With regard to the addition of other antihistamines or concomitant use of antiallergic drugs with different mechanisms of action, drug-drug interaction can be a problem. Therefore, $\mathrm{H}_{1}$ antihistamines should preferably be devoid of metabolism by the cytochrome P450 system or inhibition of the system $[1,30,51]$. Bilastine, which is minimally metabolized in the body, satisfies these requirements [7,56].

Communication between physicians and patients is important for the treatment of allergic rhinitis [1,2]. Understanding of not only the symptoms but also the life pattern and degree of treatment satisfaction of the patients and their desire regarding economy/cost may also be necessary. When prescribing $\mathrm{H}_{1}$ antihistamines, physicians should confirm concomitantly used drugs if any, select non-sedating antihistamines with as few drug-drug interactions as possible, and explain the benefits and risks of the selected drug to the patients.

\section{Article Highlights Box}

- In selecting antihistamines for allergic rhinitis, it is particularly important for safety that the selected drug does not have central depressant/sedative properties and anticholinergic effects.

- Differences in sedative effects and anticholinergic effects were observed among the secondgeneration antihistamines.

- Based on the brain $\mathrm{H}_{1}$ receptor occupancy, which is an index of sedative properties, fexofenadine and bilastine belonging to the non-sedating group can be distinguished as "non-brain-penetrating antihistamines".

- No major differences in efficacy are observed among recent, representative, non-sedating antihistamines for allergic rhinitis.

- Central nervous system safety of antihistamines needs to be evaluated not only by subjective indices, such as drowsiness, but also by the results of objective performance tests.

- Non-brain-penetrating antihistamines have been confirmed not to show sedative properties even at twice the usual dose and thus are considered to be the first-line antihistamines for allergic rhinitis.

Author Contributions: H.K. and K.Y. wrote the manuscript and D.-Y.W. and K.O. participated in the data collection and analysis. K.I. was responsible for literature review and data interpretation. All the authors read and approved the final form of the manuscript.

Acknowledgments: This work was supported in part by Grants-in-Aid for Scientific Research (\#26253016 and \#26670117 from the Japan Society for Promotion of Science (JSPS). The publication of this review was supported by a grant from Meiji Seika Pharma.

Conflicts of Interest: The corresponding author (K.Y.) received research grants from Meiji Seika Pharma, Glaxo Smith Kline, Taiho Pharma, Sanofi, Kyorin Pharmaceutical Company. In the last three years, K.Y. had received honoraria from manufactures of 2nd generation antihistamines, including Sanofi, GlaxoSmithKline, Kyowa-Kirin, Taiho Pharma, Meiji Seika Pharma, and Mitsubishi Tanabe Pharma. Other authors have similar conflicts of interest. The contents regarding all aspects of the review were made by all academic authors without consulting with the respective pharmaceutical companies. The role of author from the pharmaceutical industry (K.I.) is the confirmation of description from the points of compilation for approved drug package information. 


\section{Abbreviations}

$\begin{array}{ll}\mathrm{H}_{1} \mathrm{RO} & \text { Brain } \mathrm{H} 1 \text { receptor occupancy } \\ \text { GPCR } & \text { G-protein-coupled receptors } \\ \text { PIR } & \text { proportional impairment ratio } \\ \text { CONGA } & \text { Consensus Group of New Generation of Antihistamines } \\ \text { BBB } & \text { blood-brain barrier } \\ \mathrm{pKa} & \text { Acid-Base Dissociation Constant } \\ T_{\text {max }} & \text { time to maximum plasma concentration } \\ \mathrm{t}_{\frac{1}{2}} & \text { elimination half-life } \\ \text { ARIA } & \text { Allergic Rhinitis and its Impact on Asthma } \\ \text { SAR } & \text { seasonal allergic rhinitis } \\ \text { TSS } & \text { total symptom score } \\ \text { NSS } & \text { nasal symptom score } \\ \text { NNSS } & \text { non-nasal symptom score } \\ \text { PAR } & \text { perennial allergic rhinitis } \\ \text { FMT } & \text { Fine Motoric Test } \\ \text { CFF } & \text { Critical Flicker-Fusion Frequency Test } \\ \text { D2T } & \text { "d2" Cancellation Test } \\ \text { SRT } & \text { Simple Reaction Time } \\ \text { SDLP } & \text { standard deviations of lateral position }\end{array}$

\section{References}

1. Bousquet, J.; Khaltaev, N.; Cruz, A.A.; Denburg, J.; Fokkens, W.J.; Togias, A.; Zuberbier, T.; Baena-Cagnani, C.E.; Canonica, G.W.; van Weel, C.; et al. Allergic Rhinitis and its Impact on Asthma (ARIA) 2008. Allergy 2008, 63 (Suppl. 86), 8-160.

2. Okubo, K.; Kurono, Y.; Ichimura, K.; Enomoto, T.; Okamoto, Y.; Kawauchi, H.; Suzaki, H.; Fujieda, S.; Masuyama, K. Japanese guidelines for allergic rhinitis 2017. Allergol. Int. 2017, 66, 205-219. [CrossRef] [PubMed]

3. Kay, A.B. Allergy and allergic diseases. First of two parts. N. Engl. J. Med. 2001, 344, 30-37. [CrossRef] [PubMed]

4. Wang, D.; Clement, P.; Smitz, J.; De Waele, M.; Derde, M.P. Correlations between complaints, inflammatory cells and mediator concentrations in nasalsecretions after nasal allergen challenge and during natural allergen exposure. Int. Arch. Allergy Immunol. 1995, 106, 278-285. [CrossRef] [PubMed]

5. Mandhane, S.N.; Shah, J.H.; Thennati, R. Allergic rhinitis: An update on disease, present treatments and future prospects. Int. Immunopharmacol. 2011, 11, 1646-1662. [CrossRef] [PubMed]

6. Wang, D.Y.; Ghoshal, A.G.; Bin Abdul Muttalif, A.R.; Lin, H.C.; Thanaviratananich, S.; Bagga, S.; Faruqi, R.; Sajjan, S.; Brnabic, A.J.; Dehle, F.C.; et al. Quality of life and economic burden of respiratory disease in Asia-Pacific-Asia-Pacific Burden of Respiratory Diseases Study. Value Health Reg. Issues 2016, 9, $72-77$. [CrossRef] [PubMed]

7. Wang, X.Y.; Lim-Jurado, M.; Prepageran, N.; Tantilipikorn, P.; Wang de, Y. Treatment of allergic rhinitis and urticaria: A review of the newest antihistamine drug bilastine. Ther. Clin. Risk Manag. 2016, 12, 585-597. [CrossRef] [PubMed]

8. Yanai, K.; Yoshikawa, T.; Yanai, A.; Nakamura, T.; Iida, T.; Leurs, R.; Tashiro, M. The clinical pharmacology of non-sedating antihistamines. Pharmacol. Ther. 2017, 178, 148-156. [CrossRef]

9. Yanai, K.; Zhang, D.; Tashiro, M.; Yoshikawa, T.; Naganuma, F.; Harada, R.; Nakamura, T.; Shibuya, K.; Okamura, N. Positron emission tomography evaluation of sedative properties of antihistamines. Expert Opin. Drug Saf. 2011, 10, 613-622. [CrossRef]

10. Panula, P.; Chazot, P.L.; Cowart, M.; Gutzmer, R.; Leurs, R.; Liu, W.L.; Stark, H.; Thurmond, R.L.; Haas, H.L. International Union of Basic and Clinical Pharmacology. XCVIII. Histamine receptors. Pharmacol. Rev. 2015, 67, 601-655. [CrossRef]

11. Leurs, R.; Church, M.K.; Taglialatela, M. $\mathrm{H}_{1}$-antihistamines: Inverse agonism, anti-inflammatory actions and cardiac effects. Clin. Exp. Allergy 2002, 32, 489-498. [CrossRef] 
12. Church, D.S.; Church, M.K. Pharmacology of antihistamines. World Allergy Organ. J. 2011, 4 (Suppl. 3), S22-S27. [CrossRef]

13. Shimamura, T.; Shiroishi, M.; Weyand, S.; Tsujimoto, H.; Winter, G.; Katritch, V.; Abagyan, R.; Cherezov, V.; Liu, W.; Han, G.W.; et al. Structure of the human histamine $\mathrm{H}_{1}$ receptor complex with doxepin. Nature 2011, 475, 65-70. [CrossRef]

14. Haas, H.; Panula, P. The role of histamine and the tuberomamillary nucleus in the nervous system. Nat. Rev. Neurosci. 2003, 4, 121-130. [CrossRef] [PubMed]

15. Haas, H.; Sergeeva, O.A.; Selbach, O. Histamine in the nervous system. Physiol. Rev. 2008, 88, $1183-1241$. [CrossRef] [PubMed]

16. Shan, L.; Dauvilliers, Y.; Siegel, J.M. Interactions of the histamine and hypocretin systems in CNS disorders. Nat. Rev. Neurol. 2015, 11, 401-413. [CrossRef] [PubMed]

17. Watanabe, T.; Yanai, K. Studies on functional roles of the histaminergic neuron system by using pharmacological agents, knockout mice and positron emission tomography. Tohoku J. Exp. Med. 2001, 195, 197-217. [CrossRef]

18. Yanai, K.; Ryu, J.H.; Watanabe, T.; Iwata, R.; Ido, T.; Sawai, Y.; Ito, K.; Itoh, M. Histamine $\mathrm{H}_{1}$ receptor occupancy in human brains after single oral doses of histamine $\mathrm{H}_{1}$ antagonists measured by positron emission tomography. Br. J. Pharmacol. 1995, 116, 1649-1655. [CrossRef]

19. Okamura, N.; Yanai, K.; Higuchi, M.; Sakai, J.; Iwata, R.; Ido, T.; Sasaki, H.; Watanabe, T.; Itoh, M. Functional neuroimaging of cognition impaired by a classical antihistamine, d-chlorpheniramine. Br. J. Pharmacol. 2000, 129, 115-123. [CrossRef]

20. Tagawa, M.; Kano, M.; Okamura, N.; Higuchi, M.; Matsuda, M.; Mizuki, Y.; Arai, H.; Iwata, R.; Fujii, T.; Komemushi, S.; et al. Neuroimaging of histamine $\mathrm{H}_{1}$-receptor occupancy in human brain by positron emission tomography (PET): A comparative study of ebastine, a second-generation antihistamine and (+)-chlorpheniramine, a classical antihistamine. Br. J. Clin. Pharmacol. 2001, 52, 501-509. [CrossRef]

21. Tashiro, M.; Sakurada, Y.; Iwabuchi, K.; Mochizuki, H.; Kato, M.; Aoki, M.; Funaki, Y.; Itoh, M.; Iwata, R.; Wong, D.F.; et al. Central effects of fexofenadine and cetirizine: Measurement of psychomotor performance, subjective sleepiness, and brain histamine $\mathrm{H}_{1}$-receptor occupancy using ${ }^{11} \mathrm{C}$-doxepin positron emission tomography. J. Clin. Pharmacol. 2004, 44, 890-900. [CrossRef] [PubMed]

22. Hiraoka, K.; Tashiro, M.; Grobosch, T.; Maurer, M.; Oda, K.; Toyohara, J.; Ishii, K.; Ishiwata, K.; Yanai, K. Brain histamine $\mathrm{H}_{1}$ receptor occupancy measured by PET after oral administration of levocetirizine, a non-sedating antihistamine. Expert Opin. Drug Saf. 2015, 14, 199-206. [CrossRef] [PubMed]

23. Yanai, K.; Watanabe, T.; Yokoyama, H.; Hatazawa, J.; Iwata, R.; Ishiwata, K.; Meguro, K.; Itoh, M.; Takahashi, T.; Ido, T.; et al. Mapping of histamine $\mathrm{H}_{1}$ receptors in the human brain using $\left[{ }^{11} \mathrm{C}\right]$ pyrilamine and positron emission tomography. J. Neurochem. 1992, 59, 128-136. [CrossRef]

24. Yanai, K.; Watanabe, T.; Yokoyama, H.; Meguro, K.; Hatazawa, J.; Itoh, M.; Iwata, R.; Ishiwata, K.; Takahashi, T.; Ido, T. Histamine $\mathrm{H}_{1}$ receptors in human brain visualized in vivo by $\left[{ }^{11} \mathrm{C}\right]$ doxepin and positron emission tomography. Neurosci. Lett. 1992, 137, 145-148. [CrossRef]

25. Yanai, K.; Watanabe, T.; Meguro, K.; Yokoyama, H.; Sato, I.; Sasano, H.; Itoh, M.; Iwata, R.; Takahashi, T.; Ido, T. Age-dependent decrease in histamine $\mathrm{H}_{1}$ receptor in human brains revealed by PET. Neuroreport 1992, 3, 433-436. [CrossRef] [PubMed]

26. Tashiro, M.; Horikawa, E.; Mochizuki, H.; Sakurada, Y.; Kato, M.; Inokuchi, T.; Ridout, F.; Hindmarch, I.; Yanai, K. Effects of fexofenadine and hydroxyzine on brake reaction time during car-driving with cellular phone use. Hum. Psychopharmacol. 2005, 20, 501-509. [CrossRef] [PubMed]

27. Shamsi, Z.; Hindmarch, I. Sedation and antihistamines: A review of inter-drug differences using proportional impairment ratios. Hum. Psychopharmacol. 2000, 15, S3-S30. [CrossRef]

28. McDonald, K.; Trick, L.; Boyle, J. Sedation and antihistamines: An update. Review of inter-drug differences using proportional impairment ratios. Hum. Psychopharmacol. 2008, 23, 555-570. [CrossRef] [PubMed]

29. Yanai, K.; Tashiro, M. The physiological and pathophysiological roles of neuronal histamine: An insight from human positron emission tomography studies. Pharmacol. Ther. 2007, 113, 1-15. [CrossRef]

30. Holgate, S.T.; Canonica, G.W.; Simons, F.E.; Taglialatela, M.; Tharp, M.; Timmerman, H.; Yanai, K. Consensus Group on New-Generation Antihistamines (CONGA): Present status and recommendations. Clin. Exp. Allergy 2003, 33, 1305-1324. [CrossRef] 
31. Farré, M.; Pérez-Mañá, C.; Papaseit, E.; Menoyo, E.; Pérez, M.; Martin, S.; Bullich, S.; Rojas, S.; Herance, J.R.; Trampal, C.; et al. Bilastine vs. hydroxyzine: Occupation of brain histamine $\mathrm{H}_{1}$-receptors evaluated by positron emission tomography in healthy volunteers. Br. J. Clin. Pharmacol. 2014, 78, 970-980. [CrossRef] [PubMed]

32. Yanai, K.; Hiraoka, K.; Kárpáti, A.; Naganuma, F.; Okamura, N.; Tashiro, M.; Nakamura, T.; Yoshikawa, T. Histamine $\mathrm{H}_{1}$ receptor occupancy in human brain. In Histamine Receptors: Preclinical and Clinical Aspects. The Receptors; Blandina, P., Passani, B.M., Eds.; Humana Press: Cham, Switzerland, 2016; Volume 28, pp. 311-326.

33. Obradovic, T.; Dobson, G.G.; Shingaki, T.; Kungu, T.; Hidalgo, I.J. Assessment of the first and second generation antihistamines brain penetration and role of P-glycoprotein. Pharm. Res. 2007, 24, 318-327. [CrossRef] [PubMed]

34. Lucero, M.L.; Gonzalo, A.; Ganza, A.; Leal, N.; Soengas, I.; Ioja, E.; Gedey, S.; Jahic, M.; Bednarczyk, D. Interactions of bilastine, a new oral $\mathrm{H}_{1}$ antihistamine, with human transporter systems. Drug Chem. Toxicol. 2012, 35 (Suppl. 1), 8-17. [CrossRef]

35. Matsumoto, Y.; Funahashi, J.; Mori, K.; Hayashi, K.; Yano, H. The noncompetitive antagonism of histamine $\mathrm{H}_{1}$ receptors expressed in Chinese hamster ovary cells by olopatadine hydrochloride: Its potency and molecular mechanism. Pharmacology 2008, 81, 266-274. [CrossRef] [PubMed]

36. Corcóstegui, R.; Labeaga, L.; Innerárity, A.; Berisa, A.; Orjales, A. Preclinical pharmacology of bilastine, a new selective histamine $\mathrm{H}_{1}$ receptor antagonist: Receptor selectivity and in vitro antihistaminic activity. Drugs R D 2005, 6, 371-384. [CrossRef]

37. Bosma, R.; van den Bor, J.; Vischer, H.F.; Labeaga, L.; Leurs, R. The long duration of action of the second generation antihistamine bilastine coincides with its long residence time at the histamine H1 receptor. Eur. J. Pharmacol. 2018, 838, 107-111. [CrossRef]

38. Church, M.K.; Maurer, M.; Simons, F.E.; Bindslev-Jensen, C.; van Cauwenberge, P.; Bousquet, J.; Holgate, S.T.; Zuberbier, T. Risk of first-generation H1-antihistamines: A GA ${ }^{2} \mathrm{LEN}$ position paper. Allergy 2010, 65, 459-466. [CrossRef]

39. Yanai, K.; Rogala, B.; Chugh, K.; Paraskakis, E.; Pampura, A.N.; Boev, R. Safety considerations in the management of allergic diseases: Focus on antihistamines. Curr. Med. Res. Opin. 2012, 28, 623-642. [CrossRef]

40. Dresser, G.K.; Bailey, D.G.; Leake, B.F.; Schwarz, U.I.; Dawson, P.A.; Freeman, D.J.; Kim, R.B. Fruit juices inhibit organic anion transporting polypeptide-mediated drug uptake to decrease the oral availability of fexofenadine. Clin. Pharmacol. Ther. 2002, 71, 11-20. [CrossRef]

41. Kuna, P.; Bachert, C.; Nowacki, Z.; van Cauwenberge, P.; Agache, I.; Fouquert, L.; Roger, A.; Sologuren, A.; Valiente, R. Efficacy and safety of bilastine $20 \mathrm{mg}$ compared with cetirizine $10 \mathrm{mg}$ and placebo for the symptomatic treatment of seasonal allergic rhinitis: A randomized, double-blind, parallel-group study. Clin. Exp. Allergy 2009, 39, 1338-1347. [CrossRef]

42. Bachert, C.; Kuna, P.; Sanquer, F.; Ivan, P.; Dimitrov, V.; Gorina, M.M.; van de Heyning, P.; Loureiro, A. Comparison of the efficacy and safety of bilastine $20 \mathrm{mg}$ vs desloratadine $5 \mathrm{mg}$ in seasonal allergic rhinitis patients. Allergy 2009, 6, 158-165. [CrossRef] [PubMed]

43. Horak, F.; Zieglmayer, P.; Zieglmayer, R.; Lemell, P. The effects of bilastine compared with cetirizine, fexofenadine, and placebo on allergen-induced nasal and ocular symptoms in patients exposed to aeroallergen in the Vienna Challenge Chamber. Inflamm. Res. 2010, 59, 391-398. [CrossRef] [PubMed]

44. Hashiguchi, K.; Wakabayashi, K.I.; Togawa, M.; Saito, A.; Okubo, K. Therapeutic effect of bilastine in Japanese cedar pollinosis using an artificial exposure chamber (OHIO Chamber). Allergol. Int. 2017, 66, 123-131. [CrossRef] [PubMed]

45. Sastre, J.; Mullol, J.; Valero, A.; Valiente, R. Efficacy and safety of bilastine $20 \mathrm{mg}$ compared with cetirizine $10 \mathrm{mg}$ and placebo in the treatment of perennial allergic rhinitis. Curr. Med. Res. Opin. 2012, 28, 121-130. [CrossRef] [PubMed]

46. Okubo, K.; Gotoh, M.; Asako, M.; Nomura, Y.; Togawa, M.; Saito, A.; Honda, T.; Ohashi, Y. Efficacy and safety of bilastine in Japanese patients with perennial allergic rhinitis: A multicenter, randomized, double-blind, placebo-controlled, parallel-group phase III study. Allergol. Int. 2017, 66, 97-105. [CrossRef] [PubMed] 
47. García-Gea, C.; Martínez-Colomer, J.; Antonijoan, R.M.; Valiente, R.; Barbanoj, M.J. Comparison of peripheral and central effects of single and repeated oral dose administrations of bilastine, a new $\mathrm{H}_{1}$ antihistamine: A dose-range study in healthy volunteers with hydroxyzine and placebo as control treatments. J. Clin. Psychopharmacol. 2008, 28, 675-685. [CrossRef]

48. Conen, S.; Theunissen, E.L.; Van Oers, A.C.; Valiente, R.; Ramaekers, J.G. Acute and subchronic effects of bilastine (20 and $40 \mathrm{mg}$ ) and hydroxyzine $(50 \mathrm{mg})$ on actual driving performance in healthy volunteers. J. Psychopharmacol. 2011, 25, 1517-1523. [CrossRef]

49. Jáuregui, I.; Ramaekers, J.G.; Yanai, K.; Farré, M.; Redondo, E.; Valiente, R.; Labeaga, L. Bilastine: A new antihistamine with an optimal benefit-to-risk ratio for safety during driving. Expert Opin. Drug Saf. 2016, 15, 89-98. [CrossRef]

50. García-Gea, C.; Martínez, J.; Ballester, M.R.; Gich, I.; Valiente, R.; Antonijoan, R.M. Psychomotor and subjective effects of bilastine, hydroxyzine, and cetirizine, in combination with alcohol: A randomized, double-blind, crossover, and positive-controlled and placebo-controlled Phase I clinical trials. Hum. Psychopharmacol. 2014, 29, 120-132. [CrossRef]

51. Brozek, J.L.; Bousquet, J.; Baena-Cagnani, C.E.; Bonini, S.; Canonica, G.W.; Casale, T.B.; van Wijk, R.G.; Ohta, K.; Zuberbier, T.; Schünemann, H.J. Allergic Rhinitis and its Impact on Asthma (ARIA) guidelines: 2010 revision. J. Allergy Clin. Immunol. 2010, 126, 466-476. [CrossRef]

52. Senda, M.; Kubo, N.; Adachi, K.; Ikari, Y.; Matsumoto, K.; Shimizu, K.; Tominaga, H. Cerebral histamine $\mathrm{H}_{1}$ receptor binding potential measured with PET under a test dose of olopatadine, an antihistamine, is reduced after repeated administration of olopatadine. J. Nucl. Med. 2009, 50, 887-892. [CrossRef] [PubMed]

53. Novák, Z.; Yáñez, A.; Kiss, I.; Kuna, P.; Tortajada-Girbés, M.; Valiente, R. Safety and tolerability of bilastine 10 mg administered for 12 weeks in children with allergic diseases. Pediatr. Allergy Immunol. 2016, 27, 493-498. [CrossRef] [PubMed]

54. Zuberbier, T.; Aberer, W.; Asero, R.; Bindslev-Jensen, C.; Brzoza, Z.; Canonica, G.W.; Church, M.K.; Ensina, L.F.; Giménez-Arnau, A.; Godse, K.; et al. The EAACI/GA2 LEN/EDF/WAO Guideline for the definition, classification, diagnosis, and management of urticaria: The 2013 revision and update. Allergy 2014, 69, 868-887. [CrossRef] [PubMed]

55. Krause, K.; Spohr, A.; Zuberbier, T.; Church, M.K.; Maurer, M. Up-dosing with bilastine results in improved effectiveness in cold contact urticaria. Allergy 2013, 68, 921-928. [CrossRef] [PubMed]

56. Church, M.K. Safety and efficacy of bilastine: A new $\mathrm{H}_{1}$-antihistamine for the treatment of allergic rhinoconjunctivitis and urticaria. Expert Opin. Drug Saf. 2011, 10, 779-793. [CrossRef] [PubMed]

57. Antonijoan, R.; Coimbra, J.; García-Gea, C.; Puntes, M.; Gich, I.; Campo, C.; Valiente, R.; Labeaga, L. Comparative efficacy of bilastine, desloratadine and rupatadine in the suppression of wheal and flare response induced by intradermal histamine in healthy volunteers. Curr. Med. Res. Opin. 2017, 33, 129-136. [CrossRef] [PubMed]

58. Jutel, M.; Watanabe, T.; Klunker, S.; Akdis, M.; Thomet, O.A.; Malolepszy, J.; Zak-Nejmark, T.; Koga, R.; Kobayashi, T.; Blaser, K.; et al. Histamine regulates T-cell and antibody responses by differential expression of $\mathrm{H}_{1}$ and $\mathrm{H}_{2}$ receptors. Nature 2001, 413, 420-425. [CrossRef]

(C) 2019 by the authors. Licensee MDPI, Basel, Switzerland. This article is an open access article distributed under the terms and conditions of the Creative Commons Attribution (CC BY) license (http:/ / creativecommons.org/licenses/by/4.0/). 